\title{
Seasonal Change in Oxidative Stress Markers in Blood Plasma of Tharparkar (Bos indicus) and Karan Fries (Bos indicus $\boldsymbol{x}$ Bos taurus) Cattle under Tropical Climate
}

\author{
Uttarani Maibam $^{1}$, Om K. Hooda ${ }^{1}$, Phurailatpam S. Sharma ${ }^{2}$, \\ Sohan V. Singh ${ }^{1}$ and Ramesh C. Upadhyay ${ }^{1}$ \\ ${ }^{1}$ Animal Physiology Division, ICAR-National Dairy Research Institute, 132001-Karnal, \\ Haryana, India \\ ${ }^{2}$ Animal Nutrition Division, ICAR-National Dairy Research Institute, 132001-Karnal, \\ Haryana, India \\ *Corresponding author
}

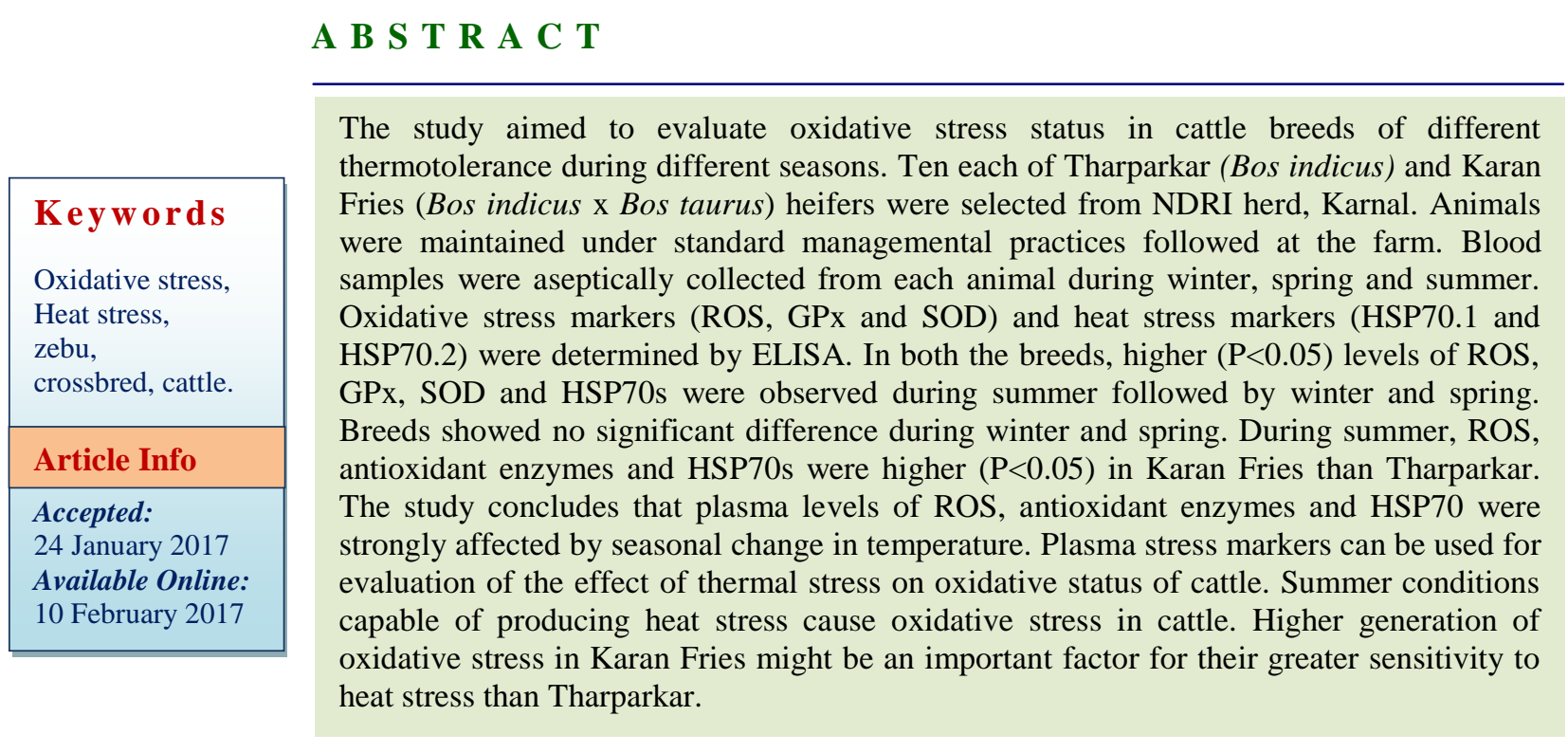

\section{Introduction}

Free radical reactions are the integral part of normal metabolism. Normally, oxidation is necessary to provide energy for maintenance of cellular integrity and functions (Miller et al., 1993). In normal cellular metabolism, low to moderate ROS is generated as part of the signaling pathways, and in innate and adaptive immune response against danger signals (Martins Chaves et al., 2000). When reactive forms of oxygen are produced faster than they can be safely neutralized by antioxidant mechanisms, oxidative stress results (Sies, 1991). OxS is considered as a part of the stress response to heat exposure (Lin et al., 2006). OxS can be induced by both exogenous and endogenous factors in living organisms (Cross et al., 1998; Lesser, 2006). Animals are exposed to a wide variety 
of environmental conditions during different seasons of the year. Physiological, biochemical, and morphological responses vary with environmental conditions and animal's genetic makeup (Maibam et al., 2014).

At the same time, the climate is changing. Significant changes in physical and biological systems have already occurred in all continents and in most oceans. Most of these changes are in them direction expected with warming temperature (Rosenzweig et al., 2008). It is also very likely that heat waves will occur with a higher frequency and duration. The Intergovernmental Panal on Climate Change (IPCC) projected that there will be an increase in temperature by $0.2^{\circ} \mathrm{C}$ per decade, and predicted that the increase in global average surface temperature would be between $1.8^{\circ} \mathrm{C}$ to $4.0^{\circ} \mathrm{C}$ by 2100 (IPCC, 2007). High environmental temperature challenges the homeostatic system and stimulates excessive production of free radicals (Bernabucci et al., 2002). Production of superoxide radicals increases from threshold concentration due to thermal stress (Ganie et al., 2013). A well organized system of both chemical and enzymatic antioxidants which work in a synergistic manner to protect it against the overload of oxidant species (Briganti and Picardo, 2003). However, continuous rise in air temperature does not protect cellular damage due to disequilibrium between diverse physiological and cellular functions (Patir and Upadhyay, 2010). These conditions can contribute or lead to the onset of health disorders in cattle (Miller et al., 1993). ROS induced damage of cells and molecules is reported to be one of the reasons responsible for the decline in an animal's performance during heat stress (Mujahid et al., 2006).

Studies on the effects of heat stress on oxidative status in cattle are lacking, and only preliminary reports are available. Oxidative stress can be monitored with several biomarkers (antioxidants and pro-oxidants) which can be assessed in plasma and/or erythrocytes (Passi et al., 2001). Zebu cattle are reported to be more heat tolerant than crossbred cattle. We assumed that the oxidative status of zebu and crossbred cattle might be impaired differentially by heat stress. Environmental conditions vary significantly during different seasons in tropical climate (Maibam et al., 2017). Therefore, we analyzed changes in several markers of oxidative status and heat stress in plasma of Tharparker and Karan Fries cattle during different seasons.

\section{Materials and Methods}

The experiment was conducted in the cattle yard of the National Dairy Research Institute (NDRI), Karnal, Haryana, altitude $250 \mathrm{~m}, 29^{\circ}$ $42^{\prime \prime} \mathrm{N}$ and $79^{\circ} 54^{\prime \prime} \mathrm{E}$. Ambient temperature ranges from near $0^{\circ} \mathrm{C}$ in winter to $45^{\circ} \mathrm{C}$ in summer, and annual rainfall averages 700 $\mathrm{mm}$.

\section{Animals and ethical permission}

Ten each of Tharparkar and Karan Fries heifers of approximately 2 years of age were selected from NDRI herd for experiments during winter, spring and summer season. All these animals were maintained under general management practices followed for heifers at the institute. At the time of the actual experiment, all the animals were clinically healthy and free from any physical or anatomical abnormalities. The experiment was approved by the Institutional Animal Ethics Committee (IAEC) constituted as per the article number 13 of the CPCSEA-rules, laid down by Government of India. Norms regarding the ethical treatment of animals during the whole operation were strictly followed. 


\section{Blood sampling and clinical parameters}

From each animal, blood samples were collected twice per season during winter (Dec-Jan), spring (Feb-Mar) and summer (May-June) season. Blood samples $(10 \mathrm{ml})$ were collected from animals by jugular vein puncture in Lithium Heparin coated Vacutainer® tubes (BD Biosciences, Franklin Lakes, NJ, USA) under aseptic conditions and were transported to the laboratory under refrigeration $\left(4^{\circ} \mathrm{C}\right)$. The collected blood samples were centrifuged at $2300 \mathrm{rpm}$ for 40 minutes to separate the plasma. Plasma samples were analysed for the levels of oxidative stress markers (ROS, GPx, SOD) and heat stress markers (HSP70.1, HSP70.2). On the day of blood sampling, skin and rectal temperature of each animal were recorded. The peripheral skin temperature at different anatomical sites viz. forehead, dorsal, and flank regions of each animal were recorded using infrared thermometer (Raytek, Model Raynger ST2L, M/s. Surrey Scientific, Surrey, U.K.) by keeping it 2-3 in. away from the skin surface site and average of different sites were taken. Rectal temperature was recorded using digital thermometer by keeping the thermometer in contact with the rectal mucosa of animal for about $2 \mathrm{~min}$. Data on meteorological variables was collected from CSSRI, Karnal and THI was calculated using the formula $0.72\left(\mathrm{Tdb}^{\circ} \mathrm{C}+\mathrm{Twb}^{\circ} \mathrm{C}\right)$ $+40.6^{\circ}$ (Johnson et al., 1963).

\section{Estimation of oxidative stress markers}

Reactive oxygen species (ROS), glutathione peroxidise (GPx) and superoxide dismutase (SOD) were determined using Bovine Reactive Oxygen Species, Bovine Glutathione Peroxidase and Bovine Superoxide Dismutase ELISA kit supplied by MyBioSource, San Diego, California, US according to the manufacturer's instructions. The sensitivity for ROS and GPx assay was $1 \mathrm{ng} / \mathrm{ml}$ and that for SOD was $0.1 \mu \mathrm{g} / \mathrm{ml}$.

\section{Estimation of heat stress markers}

Similarly, heat shock proteins viz. HSP70.1 and HSP70.2 were determined using bovine specific HSP70.1 and HSP70.2 ELISA kit, respectively supplied by MyBioSource, San Diego, California, US. The sensitivity for HSP70.1 and HSP70.2 assay kits was $1 \mathrm{ng} / \mathrm{ml}$ and $0.1 \mathrm{ng} / \mathrm{ml}$, respectively.

\section{Statistical analysis}

Data of present study were normally distributed as checked by Shapiro-Wilk test in SAS system. Data were analyzed by analysis of variance using SAS software, version (9.1) of the SAS system for Window, Copyright $(C$ (2011) SAS Institute Inc., Cary, NC, USA. Results were expressed as the means \pm SEM. A difference with value $\mathrm{P}<0.05$ was considered statistically significant.

\section{Results and Discussion}

\section{Environmental conditions and clinical parameters}

During spring, mean daily values of THI was 51.9. In winter, mean daily values of THI was equal to 64.5 and it increased to 80.7 during summer (Table 1). THI during summer was above 80 representing severe heat stress. Rectal and skin temperatures differed significantly $(\mathrm{P}<0.05)$ between seasons in both Tharparkar and Karan Fries. RT and ST were higher $(\mathrm{P}<0.05)$ in Karan Fries than Tharparkar during summer (Table 2).

\section{Oxidative stress markers}

ROS levels in blood plasma of zebu (Tharparkar) and crossbred (Karan Fries) cattle during different seasons are presented in Figure 1. Plasma ROS production was significantly $(\mathrm{P}<0.05)$ higher during winter and summer than spring season in both 
Tharparkar and Karan Fries cattle. Highest concentration of ROS was observed during summer in both the breeds. Breed differences were non-significant during spring and winter season. However, plasma ROS level was significantly $(\mathrm{P}<0.05)$ higher in Karan Fries than Tharparkar cattle during summer season.

Similarly, plasma levels of antioxidant enzymes (GPx and SOD) were also significantly $(\mathrm{P}<0.05)$ higher during winter and summer compared to spring season in both Tharparkar and Karan Fries. The two breeds showed highest concentrations of GPx and SOD during summer (Figure 2 and 3). The levels of antioxidant enzymes during winter and spring season showed no significant differences between Tharparkar and Karan Fries. But, GPx and SOD levels during summer were significantly higher in crossbred (Karan Fries) than zebu (Tharparkar) cattle.

\section{Heat stress markers}

Plasma levels of HSP70.1 and HSP70.2 levels increased significantly $(\mathrm{P}<0.05)$ during winter and summer compared to spring season in both Tharparkar and Karan Fries (Figure 4 and 5). The magnitude of increase was significantly $(\mathrm{P}<0.05)$ higher during summer than winter in both the breeds. HSP70.1 and HSP70.2 levels showed no significant differences between the breeds during winter season. However, plasma levels of HSP70i were significantly $(\mathrm{P}<0.05)$ higher in crossbred (Karan Fries) than zebu (Tharparkar) cattle during summer.

The present findings indicated that there were marked variations in the plasma levels of oxidative stress markers (ROS, GP $\mathrm{GP}_{\mathrm{x}}$ and SOD) and heat stress markers (HSP70.1 and HSP70.2) of Tharparkar and Karan Fries cattle during different seasons. The parameters under study were significantly higher during winter and summer compared to spring in both the breeds. These changes might be due to thermal (hypothermic or heat) stress induced in animals during winter and summer season. The weather conditions (Table 1) prevailed during the study was sufficient to elicit stress response to the animals. Skin and rectal temperature of Tharparkar and Karan Fries cattle also showed marked variations with seasonal change in temperature (Table 2). Bello-Klein et al., (2000) also indicated that seasonal alterations of the oxidative status depend more on weather conditions such as temperature and humidity.

The magnitude of increase in plasma levels ROS, GPx, SOD and HSP70s was higher during summer than winter in both Tharparkar and Karan Fries. Among the stressors, heat stress has been of major concern in reducing animal's productivity in tropical, sub-tropical and arid areas (Silanikove et al., 1997). Lovell et al., (2007) also reported that heat greatly accelerates the synthesis of the HSP70 and this HSP70 was found to have both cellular and systemic protective role (Kregel, 2002) Banerjee et al., (2014) reported higher expression of HSP70 during summer than winter season in goat breeds. Heat stress was also suggested to be responsible of inducing oxidative stress during summer in livestock animals (Ganaie et al., 2013; Nizar et al., 2013). Normally, oxidative metabolic process is essential to provide energy for maintenance of cellular integrity and functions (Miller et al., 1993). But, when cells are exposed to heat stress there is acceleration of mitochondrial respiration (Keller et al., 2004) and promotion of cellular oxidation. Similar findings were reported by Yang et al., (2010) who observed a significant increase in ROS and antioxidant enzymes on exposure to heat stress. Zuo et al., (2000) and Mujahid et al., (2005) demonstrated the heat-induced increase of 
ROS production. Kaldur et al., (2014) reported that heat acclimation increases OxS level in human. Kataria et al., (2010) also observed that hot environmental conditions can produce oxidative stress in cows by modulation of physiological mechanisms in response to heat stress. Bernabucci et al., (2002) demonstrated increase in level of antioxidant enzymes to neutralize the adverse effect of free radicals produced. Therefore, we speculate that the coordinate increase in plasma GPx and SOD observed in the present study is an indirect compensatory response of cells to increased oxidant challenge during heat stress. Chandra and Aggarwal (2009) also reported higher erythrocyte antioxidant enzyme levels in prepartum crossbred cows during summer than winter season. A study on the effect of winter and summer seasons on antioxidant status of growing heifers and lactating Murrah buffaloes reported significantly higher erythrocyte SOD and CAT levels during summer than winter
(Lallawmkimi, 2009). The coordinate upregulation of HSP70 observed in the present study may also potentiate the protective effect of antioxidant enzyme through its chaperone functions. It was reported that HSP upregulation reduces oxidative stress (Kalmar and Greensmith, 2009), improves antioxidant capacity and inhibits the lipid peroxidation production $(\mathrm{Gu}$ et al., 2012), thus protects the animal from harmful effects of heat stress. Similar findings were reported by Droge (2002) who observed that body releases HSPs in addition to antioxidant enzymes on exposure to heat stress to protect itself from the deleterious cellular effects of ROS.

The present investigation observed that there was no significant difference between zebu (Tharparkar) and crossbred (Karan Fries) cattle in plasma levels of ROS, GPx, SOD and HSP70s during spring and winter season.

Table.1 Mean environmental variables during different seasons of experimental period

\begin{tabular}{ccccccc}
\hline Season & Max. temp $\left({ }^{\circ} \mathrm{C}\right)$ & Min. temp $\left({ }^{\circ} \mathrm{C}\right)$ & $\mathrm{RH} \%$ & $\mathrm{~T}_{\mathrm{db}}\left({ }^{\circ} \mathrm{C}\right)$ & $\mathrm{T}_{\mathrm{wb}}\left({ }^{\circ} \mathrm{C}\right)$ & $\mathrm{THI}$ \\
\hline Thermoneutral & 23.4 & 11.4 & 75.0 & 18.0 & 15.2 & 64.5 \\
Winter & 14.8 & 6.6 & 85.5 & 11.2 & 10.0 & 51.9 \\
Summer & 40.3 & 23.6 & 43.0 & 33.1 & 22.6 & 80.7 \\
\hline
\end{tabular}

Table.2 Skin and rectal temperature of Tharparkar and Karan Fries cattle during different seasons

\begin{tabular}{lllll}
\hline \multicolumn{1}{c}{ Parameters } & \multicolumn{1}{c}{ Breeds } & \multicolumn{3}{c}{ Season } \\
\hline \multirow{3}{*}{ Skin temperature $\left({ }^{\circ} \mathrm{C}\right)$} & Tharparkar & $33.83 \pm 0.21^{\mathrm{bA}}$ & $24.77 \pm 0.63^{\mathrm{cB}}$ & Summer \\
& Karan Fries & $34.32 \pm 0.07 \pm 0.28^{\mathrm{bA}}$ & $28.97 \pm 0.55^{\mathrm{aA}}$ & $43.01 \pm 1.16^{\mathrm{aA}}$ \\
Rectal Temperature & Tharparkar & $38.41 \pm 0.06^{\mathrm{bA}}$ & $37.84 \pm 0.06^{\mathrm{cB}}$ & $38.88 \pm 0.05^{\mathrm{aB}}$ \\
& Karan Fries & $38.58 \pm 0.03^{\mathrm{bA}}$ & $38.13^{\mathrm{c}} \pm 0.07^{\mathrm{CA}}$ & $39.47^{\mathrm{d}} \pm 0.06^{\mathrm{aA}}$ \\
\hline
\end{tabular}

*Values are means \pm S.E of twenty observations of ten animals. Columns with different superscripts a, b, c and rows with different superscripts A,B differed significantly $(\mathrm{P}<0.05)$. 
Fig.1 ROS levels (ng/ml) in blood plasma of Tharparkar and Karan Fries cattle during different seasons. Bars with different superscripts a,b,c and A,B differed significantly $(\mathrm{P}<0.05)$ between seasons and breeds, respectively.

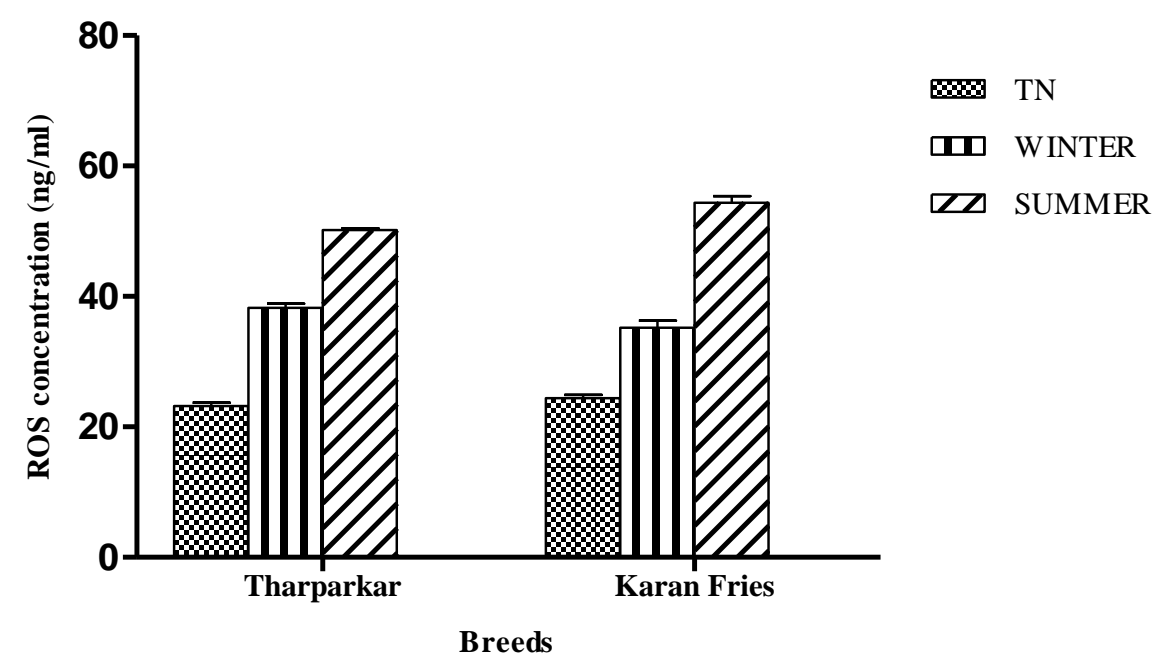

Fig.2 GPx levels (ng/ml) in blood plasma of Tharparkar and Karan Fries cattle during different seasons. Bars with different superscripts a,b,c and A,B differed significantly $(\mathrm{P}<0.05)$ between seasons and breeds, respectively.

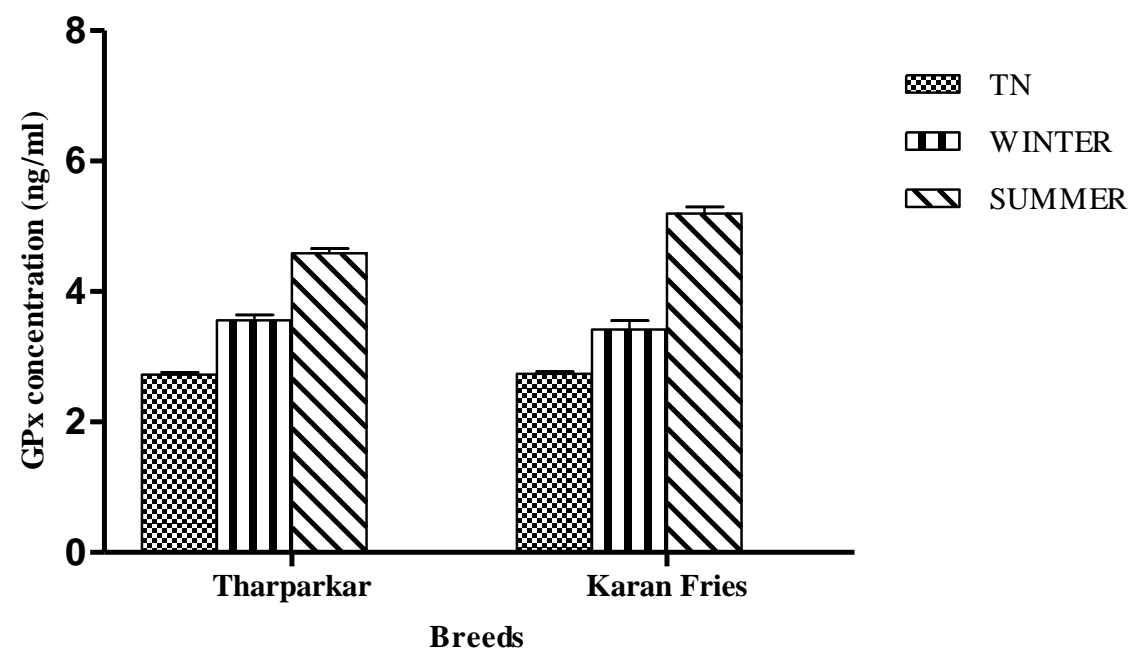


Fig.3 SOD levels (ng/ml) in blood plasma of Tharparkar and Karan Fries cattle during different seasons. Bars with different superscripts a,b,c and A,B differed significantly $(\mathrm{P}<0.05)$ between seasons and breeds, respectively.

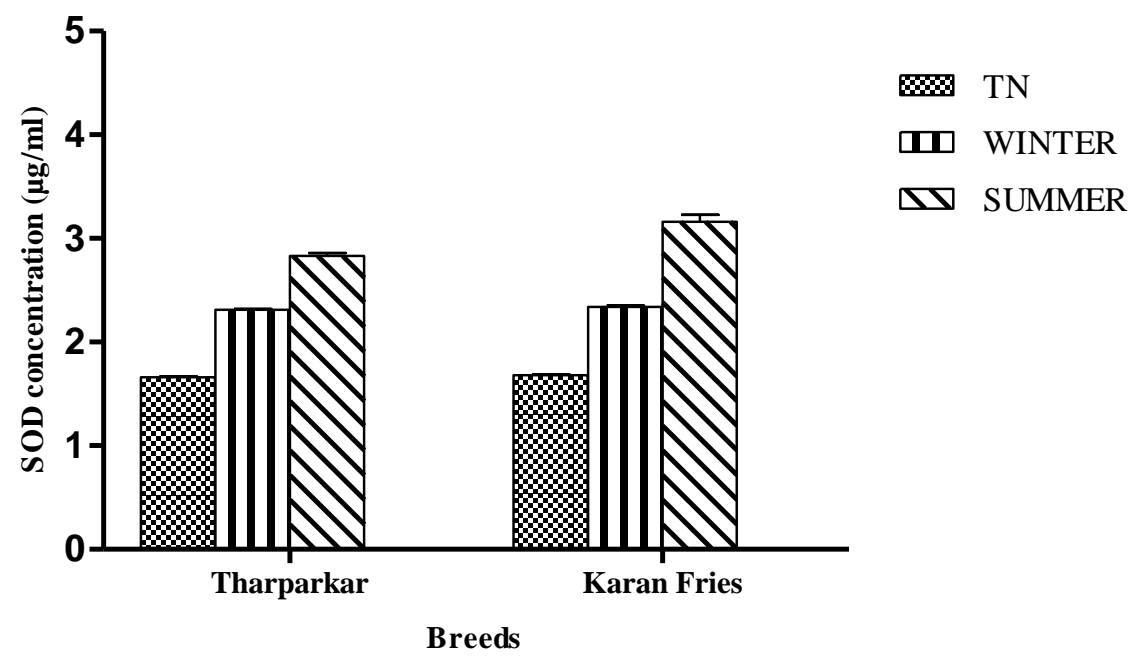

Fig.4 HSP70.1 (ng/ml) in blood plasma of Tharparkar and Karan Fries cattle during different seasons. Bars with different superscripts a,b,c and A,B differed significantly $(\mathrm{P}<0.05)$ between seasons and breeds, respectively.

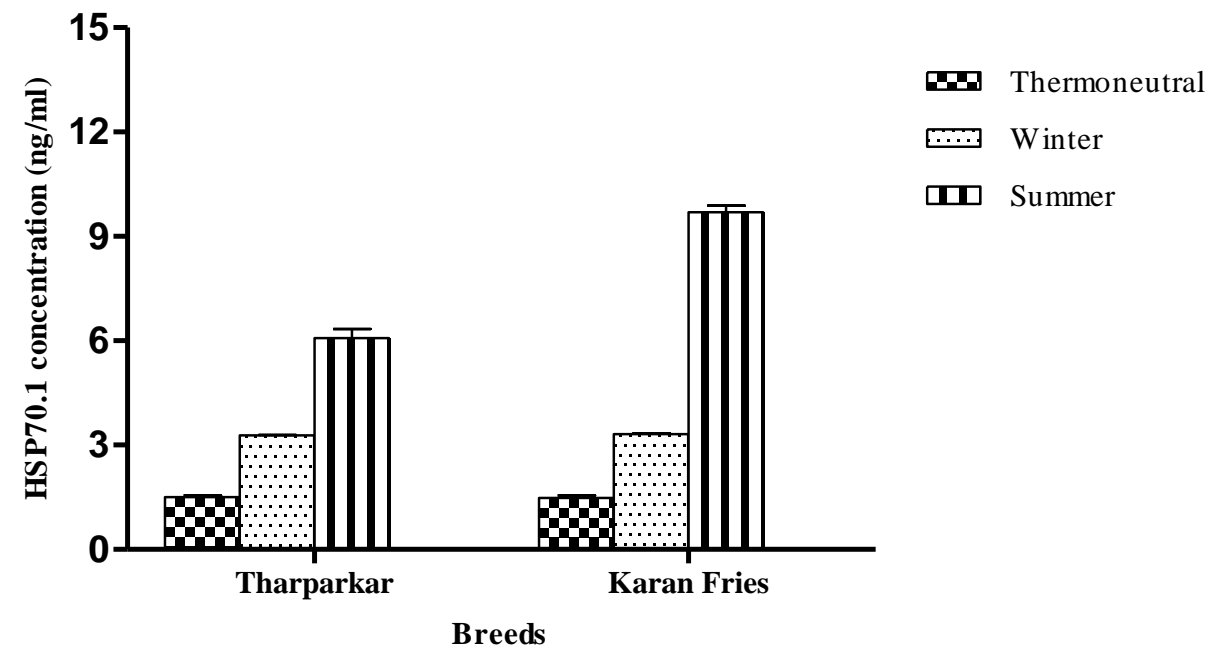


Fig.5 HSP70.2 (ng/ml) in blood plasma of Tharparkar and Karan Fries cattle during different seasons. Bars with different superscripts a,b,c and A,B differed significantly $(\mathrm{P}<0.05)$ between seasons and breeds, respectively.

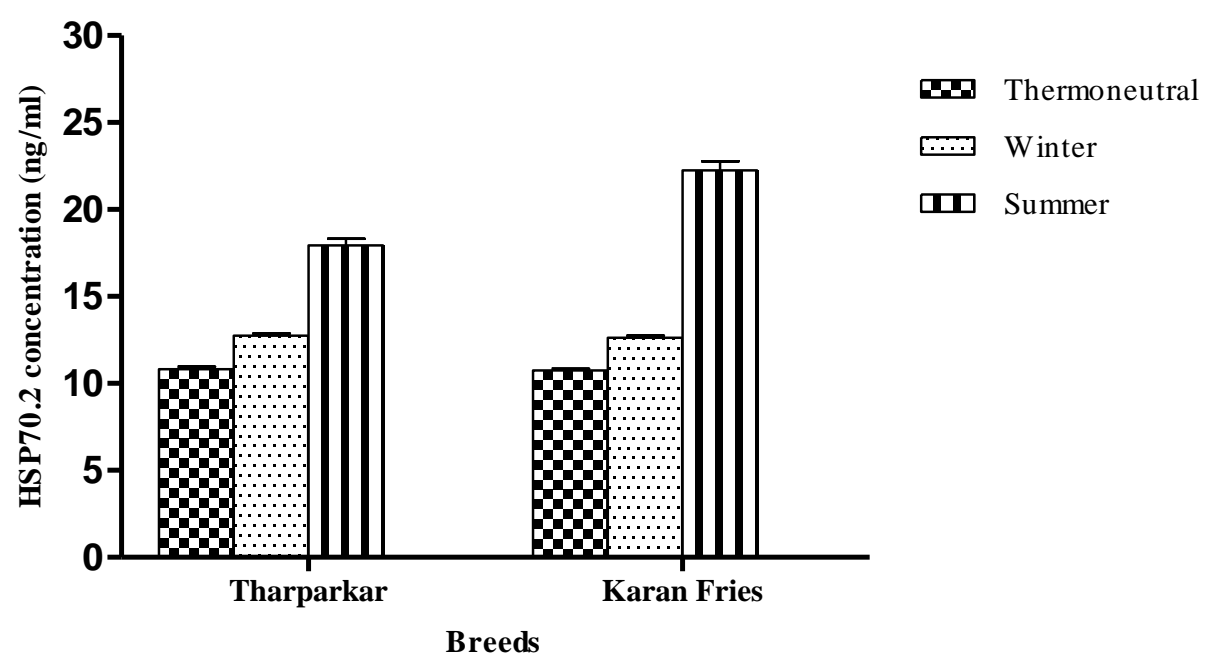

However, all these parameters were significantly higher in Karan Fries than Tharparkar during summer season. These differences might be attributed to the differences in thermotolerance of the two breeds to heat stress. The higher abundance of oxidative stress markers (ROS, GPx, SOD) and heat stress markers (HSP70.1 and HSP70.2) in Karan Fries during summer indicated that they are under more stress during summer heat than Tharparkar. Lacetera et al., (2006) reported that HSP and oxidative stress levels are one of the most important stress markers to know the animal's comfort level and adaptability. Gihan et al., (2009) reported that breeds have variations in physiological and antioxidant enzyme activities. Therefore, in the present study, higher levels of ROS, GPx, SOD and HSP70s levels in Karan Fries than Tharparkar during summer season indicated higher status of oxidative stress with greater sensitivity to heat stress.

In conclusion, increase in plasma levels of HSPS, GPx and SOD during winter and summer seasons are likely to represent adaptive changes of cattle in response to thermal stress. The difference in plasma levels of stress markers with seasonal change in environmental temperature indicates that plasma markers can be used for the evaluation of the effect of thermal stress on cattle. Summer conditions capable of producing heat stress cause oxidative stress in cattle. The generation of higher amount of reactive oxygen species and oxidative stress status in Karan Fries might be an important factor for their greater sensitivity to heat stress than Tharparkar.

\section{Acknowledgement}

The authors express sincere thanks to the Director, NDRI, Karnal, for providing necessary facilities for the research. The financial assistance received from National Initiative on Climate Resilient Agriculture (NICRA) project of Indian Council of Agricultural Research (ICAR), New Delhi, is thankfully acknowledged.

\section{References}

Banerjee, D., Upadhyay, R.C., Chaudhary, U.B., Kumar, R., Singh, S., Ashutosh, 
M., Polley, S., Mukherjee, A., Das, T.K. and De, S. 2014. Seasonal variation in expression pattern of genes under HSP70: Seasonal variation in expression pattern of genes under HSP70 family in heat- and cold-adapted goats (Capra hircus). Cell Stress and Chaperones, 19: 401-408.

Bello-Klein, A., Morgan-Martins, M.I., Barp, J., Llesuy, S., Bello, A.A. and Singal, P.K. 2000. Circaannual changes in antioxidants and oxidative stress in the heart and liver in rats. Comparative Biochemistry and Physiol., 126: 203208.

Beloor, J., Kang, H.K., Kim, Y.J., Subramani, V.K., Jang, I.S. and Sohn, S.H. 2010. The effect of stocking density on stress related genes and telomeric length in broiler chickens. Asian-Australasian. J. Animal Sci., 23: 437-443.

Bernabucci, U., Ranchi. B., Lacetara, N. and Nardone, A. 2002. Markers of oxidative status in plasma and erythrocytes of transition dairy cows during hot season. J. Dairy Sci., 85: 2173-2179.

Briganti, S. and Picardo, M.J. 2003. Antioxidant activity, lipid peroxidation and skin diseases. What's new. $J$. European Academy of Dermatol. Venereol., 17: 663-669.

Chandra, G. and Aggarwal, A. 2009. Effect of DL- $\alpha$-Tocopherol acetate on calving induced oxidative stress in periparturient crossbred cows during summer and winter seasons. Indian J. Animal Nutri., 26: 204-210.

Cross, C.E., Van der Vliet, A., Louie, S., Thiele, J.J. and Halliwell, B. 1998. Oxidative stress and antioxidants at biosurfaces: plants, skin, and respiratory tract surfaces. Environ. Health Perspectives, 106(5): 1241-1251.

Droge, W. 2002. Free radicals in the physiological control of cell function. Physiol. Rev., 82: 47-95.
Ganaie, A.H., Shanker, G., Bumla, N.A., Ghasura, R.S., Mir, N.A.. 2013. Biochemical and Physiological Changes during Thermal Stress in Bovines. J. Vet. Sci. Technol., 4: 1-6. doi:10.4172/2157-7579.1000126.

Gihan, S., Farahat, A.M., Abdel Azim, A. and Osma, M.R. 2009. Breed differences and phenotypic correlations of antioxidant enzymes activities, some physiological parameters and productive traits of chicken. Egyptian Poultry Sci., 29: 623-644.

Gu, X.H., Hao, Y. and Wang, X.L. 2012. Overexpression of heat shock protein 70 and its relationship to intestine under acute heat stress in broilers: 2. Intestinal Oxidative Stress. Poultry Sci., 91: 790799.

IPCC. 2007. The Intergovernmental Panel on Climate Change 4th Assessment report.

Johnson, H.D., Ragsdale, A.C., Berry, I.L. and Shanklin, M.D. 1963. Temperaturehumidity effects including influence of acclimation in feed and water consumption of Holstein cattle. University of Missouri College of agriculture (Experiment Station Res. Bull., 846).

Kaldur, T., Kals, J., Oopik, V., Zilmer, M., Zilmer, K., Eha, J. and Unt, E. 2014 Effects of heat acclimation on changes in oxidative stress and inflammation caused by endurance capacity test in the heat. Oxidative Medicine and Cellular Longevity, 2014: 1-8.

Kalmar, B. and Greensmith, L. 2009. Induction of heat shock proteins for protection against oxidative stress. $A d v$. Drug Delivery Reviews, 61: 310-318.

Kataria, N., Kataria, A.K., Maan, R. and Gahlot, A.K. 2010. Evaluation of oxidative stress in brucella infected cows. J. Stress Physiol. Biochem., 6: 19-31.

Keller, M., Sommer, A.M., Portner, H.O. and 
Abele, D. 2004. Seasonality of energetic functioning and production of reactive oxygen species by lugworm (Arenicola marina) mitochondria exposed to acute temperature changes. J. Experimental Biol., 207: 2529-2538.

Kregel, K.C. 2002. Invited review: heat shock proteins: modifying factors in physiological stress responses and acquired thermotolerance. J. Appl. Physiol., 92: 2177-2186.

Lacetera, N., Bernabucci, U., Scalia, D., Basirico, L., Morera, P. And Nardone, A. 2006. Heat stress elicits different responses in peripheral blood mononuclear cells from Brown Swiss and Holstein cows. J. Dairy Sci. 89: 4606-4612.

Lallawmkimi, C.M. 2009: Impact of thermal stress and vitamin E supplementation on heat shock protein 72 and antioxidant enzymes in Murrah Buffaloes. Ph. D. Thesis submitted to NDRI deemed University, Karnal (Haryana), India.

Lesser, M.P. 2006. Oxidative stress in marine environments: biochemistry and physiological ecology. Anпиаl Review of Physiol., 68: 253-278.

Lin, H., Decuypere, E. and Buyse, J. 2006. Acute heat stress induces oxidative stress in broiler chickens. Comparative Biochemistry and Physiology Part A, Molecular \& Integrative Physiol., 144: 11-17.

Lovell, R., Madden, L., Carroll, S. and McNaughton, L. 2007. The time-profile of the PBMC HSP70 response to in vitro heat shock appears temperaturedependent. Amino Acids, 33: 137-144.

Maibam, U., Hooda, O.K., Sharma, P.S., Mohanty, A.K., Singh, S.V., and Upadhyay, R.C. 2017. Expression of HSP70 genes in skin of zebu (Tharparkar) and crossbred (Karan Fries) cattle during different seasons under tropical climatic conditions. $J$.
Thermal Biol., 63(2017): 58-64.

Maibam, U., Singh, S.V., Upadhyay, R.C., Suresh, K., Beenam and Singh A.K. Expression of skin colour genes in Tharparkar cattle during summer and winter season. J. Environ. Res. Develop., 9: 113-119, 2014.

Martins Chaves, M., Rocha-Vieira, E., Pereira dos Reis, A., de Lima e Silva, R., Gerzstein, N.C. and Nogueira-Machado, J.A. 2000. Increase of reactive oxygen (ROS) and nitrogen (RNS) species generated by phagocyting granulocytes related to age. Mechanisms of Ageing and Development, 119: 1-8.

Miller, J.K., Brzezinska-Slebodzinska, E. and Madsen, F.C. 1993. Oxidative stress, antioxidants, and animal function. $J$. Dairy Sci., 76: 2812-2823.

Mujahid, A., Sato, K., Akiba, Y. and Toyomizu, M. 2006. Acute heat stress stimulates mitochondrial superoxide production in broiler skeletal muscle, possibly via down-regulation of uncoupling protein content. Poultry Sci., 85: 1259-1265.

Mujahid, A., Yoshiki, Y., Akiba, Y. and Toyomizu, M. 2005: Superoxide radical production in chicken skeletal muscle induced by acute heat stress. Poultry Sci., 84, 307-314.

Nizar, A. N., Mudasir, S. and Hina, A. W. 2013: Oxidative stress - Threat to animal health and production. Int. J. Livestock Res., 3: 76-83.

Passi, S., Stancato, A. and Cocchi, M. 2001. A monitoring of oxidative stress of ageing and geing-related diseases. Progress in Nutrition, 3: 35-58.

Patir, H. and Upadhyay, R.C. 2010. Purification, characterization and expression kinetics of heat shock protein 70 from Bubalus bubalis. Res. Vet. Sci., 88(2): 258-262.

Rosenzweig, C., Karoly, D., Vicarelli, M., Neofotis, P., Wu, Q., Casassa, G., 
Menzel, A., Root, T.L., Estrella, N., Seguin, B., Tryjanowski, P., Liu, C., Rawlins, S. and Imeson, A. 2008. Attributing physical and biological impacts to anthropogenic climate change. Nature, 453 (May): doi:10.1038/nature06937.

Sies, H. 1991. Oxidative Stress: Oxidants and Antioxidants. Academic Press, San Diego, CA.

Silanikove, N., Maltz, E., Halevi, A. and Shinder, D. 1997. Metabolism of water, sodium, potassium and chloride by high yielding dairy cows at the onset of lactation. J. Dairy Sci., 80: 949-956.

Yang, L., Tan, G.Y., Fu, Y.Q., Feng, J.H. and
Zhang, M.H. 2010. Effects of acute heat stress and subsequent stress removal on function of hepatic mitochondrial respiration, ROS production and lipid peroxidation in broiler chickens. Comparative Biochem. Physiol. Part C: Toxicol. Pharmacol., 151: 204208.

Zuo, L., Christofi, F.L., Wright, V.P., LiuC, Y., Merola, A.J., Berliner, L.J., Clanton, T.L. 2000: Intra- and extracellular measurement of reactive oxygen species produced during heat stress in diaphragm muscle. American J. Physiol. Cell Physiol., 279: C1058-C1066.

\section{How to cite this article:}

Uttarani Maibam, Om K. Hooda, Phurailatpam S. Sharma, Sohan V. Singh and Ramesh C. Upadhyay. 2017. Seasonal Change in Oxidative Stress Markers in Blood Plasma of Tharparkar (Bos indicus) and Karan Fries (Bos indicus $x$ Bos taurus) Cattle under Tropical Climate. Int.J.Curr.Microbiol.App.Sci. 6(2): 1720-1730. doi: http://dx.doi.org/10.20546/ijcmas.2017.602.192 